\title{
Social health insurance in the Philippines: do the poor really benefit?
}

\section{Salaheddine El Omari ${ }^{1} \cdot$ Mahmoud Karasneh $^{1}$}

Published online: 17 September 2020

(C) The Author(s) 2020

\begin{abstract}
Developing countries have spent a tremendous amount of time and money on social health insurance programs to give the low-income population free access to health care services. Standard economic theory predicts that people use care services more frequently and regularly when they are free. In this paper, we show that providing free access to health services might not be enough to enhance the utilization of health care by indigents.
\end{abstract}

Keywords Social health insurance $\cdot$ Healthcare access $\cdot$ Health care utilization · Impact evaluation · Indigents · Philippines

JEL classification $\mathrm{I} 13 \cdot \mathrm{I} 15 \cdot \mathrm{O} 11 \cdot \mathrm{O} 53$

\section{Introduction}

Social health insurance is one possible way of financing health care services. It aims to reduce health inequalities by offering low-income households free access to medical services. According to standard economic theory, social health insurance improves the use of medical care by reducing the cost of care for indigent patients (Trujillo et al. (2005)). This theory is confirmed in developed countries, as shown by Buchmueller et al. (2005); Hadley (2003), among others. However, in the context of developing countries, there is no consensus among economists that health insurance coverage improves the use of health care services by indigents. Some empirical studies have reported favorable and statistically significant effects of social health insurance on the use of health care by indigent members (Galarraga et al. (2010); Panpiemras et al. (2011); Wagstaff and Pradhan (2005), among others), while other studies do not show

Salaheddine El Omari

selomari@qu.edu.qa

1 Department of Finance and Economics, Qatar University, Doha, Qatar 
any significant impact (Bauhoff et al. (2011); King et al. (2009); Thornton et al. (2010); Wagstaff and Moreno-Serra (2009); among others).

In recent years, there has been an increasing interest in social health insurance programs and high-quality impact evaluation (see, for example, Savedoff et al. (2006) and Simon and Barmeier (2010)). Giedion et al. (2013), in their review of research published in the past 15 years on the impact of health insurance programs in developing countries, indicate that approximately $40 \%$ of all reviewed studies resort to either multivariate analysis or simple mean comparisons. The empirical evidence based on these evaluation methods generally suggests a positive effect of participation in health insurance programs on the use of health care by low-income households (Makinen and Konate (2005); Scheil-Adlung and Jütting (2006), among others). However, these methods might not be appropriate for identifying the causal effect of an insurance health program in the absence of randomization. Indeed, the group of participating members and that of non-participants are likely to be distinguished by characteristics that influence recourse to healthcare, such as age, education, income, and health conditions. Evaluating the impact of health insurance is, methodologically, a challenging endeavor. It requires the use of rigorous econometric methods to tackle different issues.

This paper evaluates the impact of the Philippine social health insurance program (hereafter PhilHealth) on the use of healthcare services by rural indigents by using a methodological protocol based on two econometric techniques: matching method and regression discontinuity design. The use of these two evaluation methods allowed us to evaluate rigorously this program and verify whether the results depend on the approach used.

The first method allowed us to match indigent participants in PhilHealth to similar non-participants, based on their propensity score. This score, which is the probability of an indigent household head being accepted into this program, was estimated using a probit model with the following explanatory variables: the age of the head of household, their gender, their education level, their household wealth, their health status, the household size, the distance to health centers, and the number of children who had died from diseases. The last four variables are introduced for the first time in relation to the existing literature.

Regression discontinuity design is infrequently used in economics as a source of identifying information in evaluating a program's effects. The major advantage of this method is that it bypasses many of the questions concerning model specification (Hahn et al. 2001). Knowing that the Philippine program of social health insurance requires that the dependent (child of the participating indigent) be under the age of 21 to profit from the advantages of the program, we have taken advantage of this eligibility condition to use this precise evaluation technique.

The paper is organized as follows. The first section provides a short description of the PhilHealth healthcare program. Section two sketches out the methodology used to evaluate the impact of this program on the use of health care by rural indigents. Section three presents the impact evaluation results. A final section expresses our conclusions and recommendations. 


\section{Philippine social health program}

\subsection{Description and objective}

The Philippine Health Insurance Corporation was created in 1995 to implement universal health coverage in the Philippines. This new national health insurance program (PhilHealth) aims to ensure the best health outcomes for all, without any form of inequity, and to protect all families, especially the poor, marginalized, and vulnerable, against the prohibitive costs of health care. It has four membership categories:

(i) Members of the formal economy, including employees in the government and private sectors, whose premium contribution payments are evenly shared by the employee and employer (1.25\% each of payroll);

(ii) Indigents or persons who have no visible source of income, or whose income is insufficient for the subsistence of the household, as identified by the Department of Social Welfare and Development, based on specific criteria set for this purpose. The annual premiums of selected beneficiaries are subsidized through a costsharing agreement between the national and local government units. In 2014, this category represented $49 \%$ of the total members covered by PhilHealth;

(iii) Self-employed members whose income is derived purely from business or professional practice. Their contributions are based on household earnings and assets, which should not exceed $3 \%$ of their estimated monthly salaries; and

(iv) Lifetime members or those former members who have reached the age of 60 and have paid at least 120 monthly contributions with PhilHealth prior to the semester of their retirement. Membership becomes free if one qualifies for both (Dayrit et al. (2018)).

Under each member category, the legal dependents of the principal member (spouse and all children below 21 years of age) have free access to health care services offered by PhilHealth. Table 1 provides a short overview of the background characteristics of PhilHealth members.

The health benefits package includes both inpatient and outpatient care, but is more inpatient-oriented (Jowett and Hsiao 2007). The benefits include room and board, professional healthcare services, diagnostics and other medical examination services, maternity care, use of surgical or medical equipment, prescription drugs and biologicals, and personal preventive services.

\subsection{Access to health Care Services for Indigents}

In 1997, PhilHealth introduced a special Indigent Program for needy families, in which premiums are supported by government subsidies, co-financed by the national and local governments. The number of indigent families covered by this program increased from 2904 in 1997 to $14.7 \mathrm{M}$ in 2014. The medical coverage of indigent families has surely expanded over time, but access to accredited healthcare services remains a challenge for poor Filipinos. Based on the 2013 National Demographic and Health Survey Report, the two major obstacles preventing households from visiting healthcare 
Table 1 Covered members and dependents

\begin{tabular}{llll}
\hline Sector & Members & Dependents & Beneficiaries \\
\hline Members in the Formal Economy & & & \\
- Private & $12,465,283$ & $10,839,327$ & $23,304,610$ \\
- Government & $2,102,361$ & $3,783,503$ & $5,885,864$ \\
- Household help & 67,598 & 49,952 & 117,550 \\
- Enterprise owners and family drivers & 946 & 1321 & 2267 \\
Members in the informal economy & & & \\
- Migrant worker & 659,311 & 951,543 & $1,610,854$ \\
- Informal sector & $2,177,414$ & $3,349,326$ & $5,526,740$ \\
- Self-earning individual & 409,751 & 586,676 & 996,427 \\
- Organized group and others & 14,335 & 19,855 & 34,190 \\
Indigents & $14,641,685$ & $28,844,119$ & $43,485,804$ \\
Sponsored members & $1,217,941$ & $1,560,458$ & $2,778,399$ \\
Senior citizens & $6,245,583$ & $1,328,749$ & $7,574,332$ \\
Overseas filipino workers & $1,229,641$ & 854,183 & $2,083,824$ \\
Total & $41,231,849$ & $52,169,012$ & $93,400,861$ \\
\hline
\end{tabular}

Source: Department of corporate planning, PhilHealth (Philippine Health Insurance Corporation 2014)

facilities are (i) a lack of financial resources and (ii) the geographic remoteness of facilities, especially in poor regions.

Indigents are often located great distances from healthcare facilities and face long travel times to obtain care services. In the survey mentioned above, persons who visited a healthcare facility in the 30 days prior to the survey's administration were asked how long it took to travel to the facility. Table 2 shows the average travel time to healthcare facilities. Overall, the average travel time was $34 \mathrm{~min}$. Among regions, the poorest region in the Philippines (ARMM) has the longest travel time (61 min), while the richest one (National Capital Region) has the shortest travel time (25 min). As expected, the average travel time is longer for persons in rural areas (38 $\mathrm{min}$ ) as compared to those in urban areas $(28 \mathrm{~min})$. In addition, women were asked what obstacles prevent them from obtaining medical services when they are sick. The reasons they gave were as follows: getting permission to go for treatment, getting money for treatment, distance to healthcare facilities, and not wanting to go alone. Table 3 shows that $27 \%$ of women stated that distance from a health facility is a serious obstacle. Rural women $(65 \%)$ are more likely than urban women $(51 \%)$ to report problems in accessing healthcare services. Looking at economic status, the survey shows that women from the lowest wealth quintile (52\%) were more likely than those from the highest wealth quintile $(13 \%)$ to say that remoteness of healthcare facilities prevents them from seeking health services.

In the same survey, $74 \%$ of indigent households reported that getting money for treatment was a struggle (National Statistics Office 2013). In the Philippines, out-ofpocket health expenditures increased by $150 \%$ (real) from 2000 to 2012 (Family Income and Expenditure Surveys 2012). The main driver of this increase is the cost of medicines, with the larger share of medicines in total health expenditures among the 
Table 2 Average travel time to health facility visited, Philippines 2013

\begin{tabular}{|c|c|c|}
\hline Background characteristic & Average travel time in minutes & Number \\
\hline \multicolumn{3}{|l|}{ Residence } \\
\hline Urban & 27.5 & 3081 \\
\hline Rural & 37.9 & 4339 \\
\hline \multicolumn{3}{|l|}{ Region } \\
\hline National Capital Region (4.1) & 24.5 & 842 \\
\hline Cordillera Admin Region (22.6) & 49.6 & 162 \\
\hline I - Ilocos Region (18.8) & 20.7 & 443 \\
\hline II - Cagayan Valley (17.6) & 47.3 & 318 \\
\hline III - Central Luzon (10.4) & 31.8 & 828 \\
\hline IVA - CALABARZON (12.2) & 29.9 & 938 \\
\hline IVB - MIMAROPA (24.8) & 43.7 & 255 \\
\hline $\mathrm{V}-\operatorname{Bicol}(39.5)$ & 26.5 & 625 \\
\hline VI - Western Visayas (24.4) & 35.4 & 628 \\
\hline VII - Central Visayas (29.1) & 45.1 & 459 \\
\hline VIII - Eastern Visayas (41.2) & 32.2 & 376 \\
\hline IX - Zamboanga Peninsula (37.5) & 33.4 & 292 \\
\hline X - Northern Mindanao (38.4) & 29.1 & 320 \\
\hline XI - Davao (23.5) & 48.2 & 260 \\
\hline XII - SOCCSKSARGEN (38.2) & 36.7 & 377 \\
\hline XIII - Caraga (39.5) & 33.3 & 164 \\
\hline ARMM (58.9) & 60.9 & 132 \\
\hline
\end{tabular}

Numbers between parentheses represent the poverty incidence among population (\%) by region (Philippine Statistics Authority 2014)

poor (76\%) as compared to the rich (58\%) (Bredenkamp and Buisman 2016). The high cost of medicines prevents indigents from seeking medical care even when they suspect it may be necessary and drives them to catastrophic spending. A second problem that adds to this obstacle is the low availability of medicines. Despite the enactment of two crucial acts, the Cheaper and Quality Medicines Act of 2008 and the Food and Drug Administration Act of 2009, extreme variations in the procurement of medicines were reported at both the Department of Health's hospitals and local government units (World Bank 2011).

\section{Methodology and data}

\subsection{Data}

The data used in this study were collected in the 2013 Philippines National Demographic and Health Survey (NDHS) conducted by the Philippine Statistics Authority (PSA) and sponsored by the United States Agency for International Development (USAID). This survey covered a national sample of approximately 15,000 households 
Table 3 Remoteness and access to healthcare facilities. Percentage of women who consider the remoteness of healthcare facilities as a serious problem in accessing healthcare services when they are sick, according to background characteristics

\begin{tabular}{lll}
\hline Background characteristic & Distance to health facility & Number of women \\
\hline Residence & & \\
Urban & 17.9 & 8585 \\
Rural & 38.1 & 7570 \\
Region & & \\
National Capital Region & 15.4 & 2924 \\
Cordillera Admin Region & 27.7 & 252 \\
I - Ilocos Region & 37.5 & 691 \\
II - Cagayan Valley & 33.9 & 550 \\
III - Central Luzon & 24.1 & 1720 \\
IVA - CALABARZON & 18.9 & 2293 \\
IVB - MIMAROPA & 42.2 & 372 \\
V - Bicol & 34.7 & 798 \\
VI - Western Visayas & 30.0 & 996 \\
VII - Central Visayas & 25.5 & 1030 \\
VIII - Eastern Visayas & 24.5 & 571 \\
IX - Zamboanga Peninsula & 38.5 & 725 \\
X - Northern Mindanao & 33.3 & 697 \\
XI - Davao & 28.2 & 893 \\
XII - SOCCSKSARGEN & 35.3 & 744 \\
XIII - Caraga & 34.2 & 435 \\
ARMM & 63.9 & 465 \\
Wealth quintile & & 3199 \\
Poorest & 51.7 & 3572 \\
Poorer & 34.9 & 3878 \\
Middle & 26.6 & 16,155 \\
Richer & 19.4 & 2886 \\
Richest & 13.2 & \\
Total & 27.4 & \\
\hline & & \\
\hline & & \\
\hline
\end{tabular}

Source: 2013 Philippines National Demographic and Health Survey Report

and allowed for the collection of information about 67,429 household members. The database used by our study is available on the internet (http://dhsprogram. com/data/available-datasets.cfm). The characteristics of our sample are reported in Table 4.

\subsection{Methodology}

The main objective of our study is to identify differences in health-related outcomes between indigents with insurance and those without. To achieve this aim, we applied a 
Table 4 Descriptive statistics for the two groups studied

\begin{tabular}{lll}
\hline $\begin{array}{l}\text { Group } \\
\text { Characteristics }\end{array}$ & Covered households & Non-covered households \\
\hline Number of households & 6304 & 6341 \\
Sex of head of household & $73 \%$ are male & $49 \%$ are male \\
Age of head of household & 43.3 & 42 \\
Education of head of household (Years of schooling) & 5.58 & 5.65 \\
\hline
\end{tabular}

Source: Author's calculations

methodological approach based on the use of two semi-parametric methods, namely matching and regression discontinuity design (RDD).

\subsubsection{Matching method}

Every impact evaluation method must overcome the fundamental evaluation problem and address the possible occurrence of selection bias. To address the selection problem, Rosenbaum and Rubin (1983) propose a feasible method based on the concept of propensity score and its properties. Their idea is to compare the treated and the nontreated units in an observational study or quasi-experiment.

Propensity score determination The first step in propensity score matching is to use a probit model to estimate the probability of an indigent's exposure to PhilHealth, conditional on a set of observable characteristics that may affect participation in this program. Given that the national government cannot afford to sponsor all needy people, priority is given to sick, older, and disabled indigents. These eligibility criteria were used to estimate three probit models explaining the involvement of indigents in the PhilHealth insurance program. To control the effect of the region's wealth on the participation of indigents in this program, we incorporated, into our three models, 17 dichotomous variables representing different administrative regions of the Philippines.

These models are shown in Table 5. Of the three estimated models, the third one has been held for the following reasons. First, it presents a large number of significant coefficients ( 15 versus 6 for the other two models). Second, it gives us an acceptable value of $\mathrm{R}^{2}$ (55\% against $11 \%$ for the second model). Finally, it allows us to acquire the number of observations needed for more representative and accurate results (4820 versus 3006 for the first model).

The explanatory variables included in the selected model are the sex of the head of household, their age, their educational level, their socioeconomic status (measured indirectly by the ownership of certain equipment, such as a television, a motorcycle, a certain type of toilet facilities, or a boat), the time the household requires to obtain drinking water, the health status of the household head, the distance from the household to healthcare facilities, the household size, and the number of children who had died from diseases. To the best of our knowledge, the last four variables have not been incorporated into previous studies. Given the lack of direct data on the health condition of indigents, we considered their use of traditional medicine as a good proxy for their health status. 
Table 5 Different models explaining the participation of rural indigents in PhilHealth program

\begin{tabular}{|c|c|c|c|}
\hline \multirow{2}{*}{$\begin{array}{l}\text { Dependent variable } \\
\text { Independent variables }\end{array}$} & \multicolumn{3}{|c|}{ Participation or lack of participation in PhilHealth } \\
\hline & $\begin{array}{l}\text { Estimated } \\
\text { Coefficients } \\
\text { (Model 1) }\end{array}$ & $\begin{array}{l}\text { Estimated } \\
\text { Coefficients } \\
\text { (Model 2) }\end{array}$ & $\begin{array}{l}\text { Estimated } \\
\text { Coefficients } \\
\text { (Model 3) }\end{array}$ \\
\hline Sex of head of household & $\begin{array}{l}0.047 \\
(5.21) * * *\end{array}$ & $\begin{array}{l}0.035 \\
(4.94) * * *\end{array}$ & $\begin{array}{l}0.427 \\
(8.25) * * *\end{array}$ \\
\hline Age of head of household & $\begin{array}{l}0.000 \\
(0.90)\end{array}$ & $\begin{array}{l}0.000 \\
(1.39)\end{array}$ & $\begin{array}{l}0.003 \\
(2.87) * *\end{array}$ \\
\hline Education level of head of household & & & $\begin{array}{l}0.011 \\
(1.44)\end{array}$ \\
\hline Telephone ownership & & $\begin{array}{l}0.006 \\
(0.33)\end{array}$ & $\begin{array}{l}-0.027 \\
(1.75) *\end{array}$ \\
\hline Motorcycle ownership & & $\begin{array}{l}-0.000 \\
(0.03)\end{array}$ & $\begin{array}{l}-0.011 \\
(-1.66) *\end{array}$ \\
\hline Time to obtain drinking water & $\begin{array}{l}0.011 \\
(2.71) * *\end{array}$ & $\begin{array}{l}0.003 \\
(2.71) * *\end{array}$ & $\begin{array}{l}0.01 \\
(2.22) * *\end{array}$ \\
\hline Television ownership & $\begin{array}{l}0.003 \\
(0.23)\end{array}$ & & $\begin{array}{l}-0.004 \\
(-1.67) *\end{array}$ \\
\hline Bicycle ownership & $\begin{array}{l}-0.010 \\
(0.87)\end{array}$ & $\begin{array}{l}-0.005 \\
(0.68)\end{array}$ & $\begin{array}{l}-0.004 \\
(-0.60)\end{array}$ \\
\hline Type of toilet facilities & $\begin{array}{l}-0.002 \\
(2.63) * * *\end{array}$ & $\begin{array}{l}-0.001 \\
(3.22) * * *\end{array}$ & $\begin{array}{l}-0.002 \\
(-4.86) * * *\end{array}$ \\
\hline Boat ownership & $\begin{array}{l}-0.042 \\
(2.32) * *\end{array}$ & $\begin{array}{l}-0.026 \\
(2.89) * * *\end{array}$ & $\begin{array}{l}-0.027 \\
(-3.18) * *\end{array}$ \\
\hline Use of traditional medicine & $\begin{array}{l}0.006 \\
(0.27)\end{array}$ & $\begin{array}{l}0.016 \\
(1.67) *\end{array}$ & $\begin{array}{l}0.002 \\
(2.98) * * *\end{array}$ \\
\hline Presence of medical history & & & $\begin{array}{l}0.050 \\
(2.86) * * *\end{array}$ \\
\hline Number of household members & $\begin{array}{l}0.005 \\
(2.64) * * *\end{array}$ & $\begin{array}{l}0.003 \\
(2.90) * * *\end{array}$ & $\begin{array}{l}0.002 \\
(2.72) * * *\end{array}$ \\
\hline Number of children killed by diseases & & & $\begin{array}{l}0.138 \\
(3.54) * * *\end{array}$ \\
\hline Access to health centers & & & $\begin{array}{l}-0.002 \\
(3.37)\end{array}$ \\
\hline Region & $\begin{array}{l}0.002 \\
(3.52) * *\end{array}$ & $\begin{array}{l}0.001 \\
(3.11) * *\end{array}$ & $\begin{array}{l}0.002 \\
(3.42) * *\end{array}$ \\
\hline Adjusted R-squared & 0.2110 & 0.1140 & 0.5551 \\
\hline Number of observations & 3006 & 4650 & 4820 \\
\hline
\end{tabular}

Statistical significance: $*$ at $10 \%$, $* *$ at $5 \%$ and $* * *$ at $1 \%$. Numbers in parentheses are the calculated "z" values

Matching techniques Once the propensity score of each rural indigent (whether participating in the PhilHealth program or not) was estimated, the next step was to select the matched samples by using matching algorithms. As recommended by Stuart and Rubin (2007) and for the sake of preciseness, we attempted to employ the four most 
common matching algorithms used in impact evaluation studies. These include nearest neighbor matching, radius matching, kernel matching, and stratification matching.

\subsubsection{Regression discontinuity design}

The PhilHealth program requires dependents of indigent members to be younger than 21 so that they can benefit from the medical coverage. We exploited this discontinuity to apply the regression discontinuity design (RDD).

This method consists of comparing the consumption of health care services between dependents just above and below the age of 21 years. The regression discontinuity model used to evaluate the impact of this program is as follows:

$$
\mathrm{Y}=\alpha+\beta_{1} \mathrm{~T}+\beta_{2} \mathrm{X}+\varepsilon
$$

Where "Y" is a discontinuous dependent variable representing the consumption of care. This variable takes the value of 1 if the dependent had consumed health care services during the 12 months preceding the survey and 0 otherwise. " $T$ " is a discontinuous explanatory variable representing PhilHealth's medical coverage, which takes the value of 1 if the dependent is covered and 0 otherwise. "X", called the selection variable, represents the age of the dependent. $\varepsilon$ is the usual error term.

From our regression discontinuity model, we can write:

- For dependents aged under 21 years:

$$
\mathrm{E}\left(\mathrm{Y} \mid \mathrm{X}=21^{-}\right)=\beta_{0}+\beta_{1}+\left(\beta_{2} * 21^{-}\right)+\mathrm{E}\left(\varepsilon \mid \mathrm{X}=21^{-}\right)
$$

- For dependents aged above 21 years:

$$
\mathrm{E}\left(\mathrm{Y} \mid \mathrm{X}=21^{+}\right)=\beta_{0}+\left(\beta_{2} * 21^{+}\right)+\mathrm{E}\left(\varepsilon \mid \mathrm{X}=21^{+}\right)
$$

where E denotes the expectation operator.

Under the assumption of similarity between the two groups of dependents, the difference between the two entities (Bredenkamp and Buisman 2016) and (Buchmueller et al. 2005) gives us the effect of medical coverage on dependents aged 20 years:

$$
\mathrm{E}\left(\mathrm{Y} \mid \mathrm{X}=21^{-}\right)-\mathrm{E}\left(\mathrm{Y} \mid \mathrm{X}=21^{+}\right)=\beta 1
$$


Consequently, a simple statistical test on the significance of the coefficient $\beta 1$ is enough to verify whether the PhilHealth indigent program had an impact on the utilization of healthcare services by dependents aged 20 years.

\section{Impact evaluation results}

\subsection{Impact of PhilHealth indigent program: A matching approach}

Based on the propensity scores estimated using the selected model, we matched rural indigent participants with a control group composed of rural indigents who are not covered by the PhilHealth program. By comparing the use of healthcare services by these two groups, we evaluated the impact of this program on the participating households.

\subsubsection{Effects on heads of participating indigent households}

Impact on healthcare utilization As shown in Table 6, the four matching techniques show that there is no significant difference between the treatment group and the control group in the use of healthcare services. This means that the PhilHealth program did not have a positive impact on the consumption of medical care by the heads of indigent households. These findings are consistent with the results of $\mathrm{Yu}$ et al. (2010); Wagstaff (2010); King et al. (2009); and Thornton et al. (2010), which show that having medical insurance does not increase the use of healthcare services. In contrast, Galarraga et al. (2010) found positive effects of Seguro Popular health insurance on the consumption of health care by Mexican indigents.

Given that the four matching methods gave the same results for all the impacts examined, we limit ourselves, in the remaining elements of our analysis, to presenting only the results procured using the Kernel-matching technique.

Table 6 Propensity-score-based impact estimates of PhilHealth on use of health care by heads of participating households

\begin{tabular}{llllll}
\hline Matching method & $\begin{array}{l}\text { Treated } \\
\text { group } \\
\text { size }\end{array}$ & $\begin{array}{l}\text { Control } \\
\text { group } \\
\text { size }\end{array}$ & $\begin{array}{l}\text { Impact } \\
\text { lestimate }\end{array}$ & $\begin{array}{l}\text { Standard deviation } \\
\text { estimated by bootstrapping } \\
\text { method* } \\
(N=100)\end{array}$ & $\begin{array}{c}t- \\
\text { value }\end{array}$ \\
\hline $\begin{array}{l}\text { Nearest neighbor matching } \\
\begin{array}{l}\text { Radius matching } \\
\quad(r=0.0001)\end{array}\end{array}$ & 2219 & 2206 & 0.021 & 0.062 & 0.330 \\
$\begin{array}{l}\text { Kernel matching } \\
\text { Stratification }\end{array}$ & 2219 & 2322 & 0.044 & 0.036 & 1.151 \\
\hline
\end{tabular}

*To determine the statistical significance of the treatment effect, the standard error may be biased because the estimated variance of the treatment effect would include the variance due to the estimation of the propensity score. One way to overcome this problem is to use bootstrapping 
Impact on perception of diseases In health care, being a well-informed consumer is essential to promoting positive results. When indigents have poor health literacy, they do not look for medical services when needed, despite the presence of health coverage. This part aims to evaluate the PhilHealth program's impact on indigents' knowledge about the most common diseases in the Philippines.

The household heads' answers to some questions in the survey on malaria, dengue, leprosy, and AIDS/HIV allowed us to assess the impact of the PhilHealth program on their knowledge about these diseases. Table 7 shows that this program had no positive effect on indigents' perception of the diseases mentioned above. Limited health literacy is correlated with low levels of education, but the level of health literacy is exacerbated by a lack of health education strategy and awareness within the policy pursued by the Philippine Health Insurance Corporation. Because of a lack of awareness, indigents often visit healthcare facilities only when their diseases have reached an advanced stage.

\subsubsection{Impacts on indigent women}

Given that we did not have accurate data on the enrollment dates of indigent rural households in the PhilHealth program, our impact analysis of this program on pregnant women was limited to the most recent pregnancies, i.e., those that took place in 2012. By doing this, we had more certainty about the medical coverage for indigent women during pregnancy and childbirth. In this part, we assess the following impacts.

Table 7 Propensity-score-based impact estimates of PhilHealth on perception of diseases by heads of participating households

\begin{tabular}{|c|c|c|c|c|c|}
\hline & $\begin{array}{l}\text { Treated } \\
\text { group } \\
\text { Size }\end{array}$ & $\begin{array}{l}\text { Control } \\
\text { group } \\
\text { Size }\end{array}$ & $\begin{array}{l}\text { Impact } \\
\text { estimate }\end{array}$ & $\begin{array}{l}\text { Standard deviation estimated by } \\
\text { bootstrapping method }(\mathrm{N}=100)\end{array}$ & $\begin{array}{r}\mathrm{t}- \\
\text { value }\end{array}$ \\
\hline \multicolumn{6}{|l|}{ Questions asked: } \\
\hline Is there a cure for leprosy? & 4180 & 4323 & 0.008 & 0.032 & 0.252 \\
\hline Is there a cure for dengue? & 4180 & 4323 & 0.014 & 0.023 & 0.609 \\
\hline $\begin{array}{l}\text { Can dengue disease be } \\
\text { prevented? }\end{array}$ & 4180 & 4323 & 0.022 & 0.034 & 0.647 \\
\hline Is malaria contagious or not? & 4180 & 4323 & 0.098 & 0.072 & 1.367 \\
\hline $\begin{array}{l}\text { Is malaria disease } \\
\text { transmissible via } \\
\text { mosquitoes? }\end{array}$ & 4180 & 4323 & 0.008 & 0.032 & 0.252 \\
\hline $\begin{array}{l}\text { Can we prevent malaria } \\
\text { disease? }\end{array}$ & 4180 & 4323 & 0.108 & 0.111 & 0.973 \\
\hline Is malaria treatable? & 4180 & 4323 & 0.203 & 0.192 & 1.057 \\
\hline $\begin{array}{l}\text { Can we protect ourselves } \\
\text { against sexual diseases? }\end{array}$ & 4180 & 4323 & 0.214 & 0.172 & 1.244 \\
\hline $\begin{array}{l}\text { Is AIDS sexually } \\
\text { transmissible? }\end{array}$ & 4180 & 4323 & 0.069 & 0.051 & 1.353 \\
\hline
\end{tabular}


Prenatal care The results presented in Table 8 show that the PhilHealth program did not have a positive impact on the use of prenatal care by indigent women. Although there is no significant difference between the two groups of matched women in terms of the consumption of prenatal care, the results show that the needy pregnant women covered by this program sought prenatal care earlier than did the non-participant indigent women. Regarding prenatal care, the results of the literature are mixed, with essential differences in outcomes across countries and research designs. Our findings are in line with those of Johar (2009), who found an increase in the use of contraceptives among indigent women covered by the Indonesian health insurance but no effect on the consumption of other services. In contrast, Smith and Sulzbach (2008) found that health insurance schemes increased the utilization of prenatal services in three West African countries (Senegal, Mali, and Ghana).

Childbirth, postnatal care, and vaccination Table 8 shows that the indigent women covered by PhilHealth had more childbirths assisted by health professionals than did those not covered by this program. This mobilization of pregnant women in search of assisted deliveries might be motivated by the high maternal mortality rate in the Philippines. Based on UNICEF's State of the World's Children 2013 report, about 3000 Filipino mothers died from childbirth out of 2.4 million deliveries (one of the highest rates in Asia). This result is consistent with that of Díaz and Jaramillo (2009), who evaluated the impacts of Peru's healthcare program and found a positive effect of this program on the number of assisted deliveries. When it comes to postnatal care, Table 8 shows that there is no statistically significant difference between the two groups of indigent women. As regards vaccination, the matching results reported in Table 9 show that there is no significant difference in immunization of children born in early 2012 between the two groups of indigent women, and this is true for all vaccines. This is partly due to the national vaccination campaign launched by the Philippine Department of Health in partnership with the World Health Organization between 2012 and 2013. This campaign has reached between $65 \%$ and $80 \%$ of Filipino children, according to the national survey conducted by the Philippine Department of Health in 2013. This result is consistent with that of Pande and Yazbeck (2003), who found that rural Indian children from

Table 8 Propensity-score-based impact estimates OF PhilHealth on use of medical services by participating women

\begin{tabular}{|c|c|c|c|c|c|}
\hline & $\begin{array}{l}\text { Treated } \\
\text { group } \\
\text { size }\end{array}$ & $\begin{array}{l}\text { Control } \\
\text { group } \\
\text { size }\end{array}$ & $\begin{array}{l}\text { Average effect of } \\
\text { treatment }\end{array}$ & $\begin{array}{l}\text { Standard deviation estimated by } \\
\text { bootstrapping method }\end{array}$ & $\mathrm{t}$-value \\
\hline Prenatal care & 1807 & 1841 & 0.085 & 0.109 & 0.778 \\
\hline $\begin{array}{l}\text { Time prior to prenatal } \\
\text { diagnosis }\end{array}$ & 1807 & 1841 & -0.324 & 0.145 & -2.234 \\
\hline $\begin{array}{l}\text { Professional assistance } \\
\text { during delivery }\end{array}$ & 1807 & 1841 & 0.234 & 0.074 & 3.161 \\
\hline Postnatal check-up & 1807 & 1841 & 0.093 & 0.156 & 0.596 \\
\hline
\end{tabular}


Table 9 Propensity-score-based impact estimates of PhilHealth on vaccination of children of participating women

\begin{tabular}{llllll}
\hline Vaccine & $\begin{array}{l}\text { Treated } \\
\text { group size }\end{array}$ & Control group size & $\begin{array}{l}\text { Average effect } \\
\text { of treatment }\end{array}$ & $\begin{array}{l}\text { Standard deviation } \\
\text { estimated by bootstrapping method }\end{array}$ & t-value \\
\hline BCG & 1807 & 1841 & 0.094 & 0.244 & 0.385 \\
DPT1 & 1807 & 1841 & 0.119 & 0.086 & 1.383 \\
Polio1 & 1807 & 1841 & 0.184 & 0.113 & 1.628 \\
DPT2 & 1807 & 1841 & 0.103 & 0.113 & 0.911 \\
DPT3 & 1807 & 1841 & 0.149 & 0.156 & 0.955 \\
Polio3 & 1807 & 1841 & 0.112 & 0.137 & 0.818 \\
Measles & 1807 & 1841 & 0.103 & 0.145 & 0.710 \\
\hline
\end{tabular}

indigent households are more likely than those from wealthy families to receive no vaccinations, even though immunization is free.

\subsection{Impact of the PhilHealth indigent program: A discontinuity regression design}

To overcome the weaknesses of the matching method, the results of which depend mainly on the model used to estimate the propensity score, we completed our analysis of impacts by using the discontinuity regression design, which is much more robust and accurate.

This method consists of comparing the consumption of healthcare services between dependents just above and below the age of 21 years. To this end, the indigent dependents were divided into two groups. The first group includes dependents between the ages of 16 and 20, and the second one comprises those between the ages of 21 and 25. This method assumes a reasonable similarity between the two groups of dependents. To verify this hypothesis, we compared the two groups mentioned above according to four criteria: gender, level of education, state of health, and socioeconomic condition. As presented in Table 10, the test for differences between the means of the two groups shows that there is no significant difference between them for all the selected criteria.

Upon verifying the hypothesis regarding the similarity between the two groups, we estimated the regression model described in the methodology section. As shown in Table 11, the significance test indicates that the coefficient $\beta 1$ is not significant, which means that the medical coverage offered by PhilHealth did not have a positive effect on the use of healthcare services by indigent dependents aged 20 years. This finding confirms the results observed among indigent household heads.

For this method, we limited our evaluation to the impact of the PhilHealth program on the use of medical services by dependents aged 20 years. This section does not evaluate the other effects assessed through the use of the matching method for the following reasons. First, for the impact of this program on the knowledge of diseases, we considered that this analysis would not be relevant, given that the covered and uncovered dependents who belong to the same household exchange knowledge and information. This exchange makes any comparison of the two groups of dependents 
Table 10 Descriptive statistics for two groups of dependents

\begin{tabular}{|c|c|c|c|}
\hline Characteristics & $\begin{array}{l}\text { Group of dependents aged } \\
\text { between } 16 \text { and } 20 \text { years } \\
\text { (Covered) }\end{array}$ & $\begin{array}{l}\text { Group of dependents aged } \\
\text { between } 21 \text { and } 25 \text { years } \\
\text { (Non-covered) }\end{array}$ & $\begin{array}{l}p \text { value } \\
\text { (Difference } \\
\text { of means } \\
\text { test) }\end{array}$ \\
\hline Number of dependents & 8433 & 8387 & - \\
\hline Sex & $65 \%$ are male & $73 \%$ are male & 0.811 \\
\hline Number of years of schooling & 8.64 & 8.96 & 0.141 \\
\hline \multicolumn{4}{|l|}{ Health status: } \\
\hline $\begin{array}{l}\text { Dependents who had used traditional } \\
\text { health care in the } 12 \text { months } \\
\text { preceding the survey }\end{array}$ & $32 \%$ & $30 \%$ & 0.912 \\
\hline $\begin{array}{l}\text { Dependents who had used alternative } \\
\text { health care in the } 12 \text { months } \\
\text { preceding the survey }\end{array}$ & $96 \%$ & $94 \%$ & 0.973 \\
\hline Proportion of smokers & $12 \%$ & $9 \%$ & 0.814 \\
\hline \multicolumn{4}{|l|}{ Socioeconomic status: } \\
\hline $\begin{array}{l}\text { Time spent collecting source water } \\
\text { (number of minutes per week) }\end{array}$ & 180 & 178 & 0.995 \\
\hline Access to electricity & $43 \%$ & $53 \%$ & 0.137 \\
\hline Television ownership & $20 \%$ & $18 \%$ & 0.812 \\
\hline Telephone ownership & $8 \%$ & $12 \%$ & 0.621 \\
\hline Radio ownership & $57 \%$ & $63 \%$ & 0.619 \\
\hline Refrigerator ownership & $2 \%$ & $4 \%$ & 0.811 \\
\hline Tractor ownership & $0 \%$ & $1 \%$ & 0.971 \\
\hline Boat ownership & $1 \%$ & $4 \%$ & 0.617 \\
\hline
\end{tabular}

Source: 2013 Philippines National Demographic and Health Survey Report

difficult. In addition, given that this program started in 2000 , there might be some dependents over the age of 21 who have already benefited from it. Second, regarding the impact of this program on vaccinations, we could not assess this impact among the young dependents because the immunization database covered only children under five years of age. Finally, we did not evaluate the effect of PhilHealth on the consumption of medical services by pregnant women aged 21 or younger because no data were available on pregnant dependents.

The results obtained from the two methods show that the PhilHealth indigent program had no impact on either the heads of indigent households or their dependents

Table 11 Discontinuity-regression-based impact estimates of PhilHealth on indigent dependents

$\begin{aligned} & \text { Dependent variable }(Y) \text { : Use of health services in the } \begin{array}{l}\text { Coefficients ( } \beta 1 \\ \text { and } \beta 2)\end{array} \\ & 12 \text { months preceding the survey. }\end{aligned}$ Standard Observed value
deviation of " $z$ "


aged 20 years. There are several plausible explanations for this finding. First, the indigent members are not well informed about their rights to free access to health care offered by health centers accredited by this program. This is due to the absence of information and awareness-raising actions within PhilHealth's policy. Indeed, 72\% of indigents interviewed in the 2013 National Demographic and Health Survey said that they did not have sufficient information about the benefits offered by this program as well as the accredited health centers. Second, as highlighted earlier in Subsection 2.2, remoteness from health care services is one of the real obstacles preventing Filipino indigents from seeking care or prevention services. Third, the scarcity of medicines in health centers and their relatively high prices discourage indigents from seeking medical help in the event of illness, as discussed earlier in Subsection 2.2. The high cost of medicines not only discourages patients from utilizing appropriate care, but also drives patients to incur catastrophic payments and impoverishing health expenditures (Bredenkamp and Buisman 2016). Finally, the presence of very popular and less expensive traditional medicine practices makes healthcare centers less attractive for indigents seeking care and treatment. The above-mentioned survey reports that $38 \%$ of the interviewed indigent households had used herbs for treatment in the three months prior to the survey interview.

\section{Conclusion}

In this paper, we evaluate the social health insurance program's success in reaching the most vulnerable groups of the population in rural and remote areas in the Philippines. For this purpose, we adopted a methodological protocol based on two rigorous micro-econometric techniques: the matching method and regression discontinuity design. The results obtained show that this program, aimed especially at helping needy families, has completely missed its target. The participating indigent households have attended healthcare facilities only for deliveries assisted by health professionals, whereas other types of care did not attract this segment of the population. This clearly demonstrates that, in the Philippine context, the provision of free access to health services might not be enough to enhance the utilization of health care by indigent families. Consequently, additional accompanying measures are needed to improve the effectiveness, efficiency, and equity of the national health insurance program in a manner that is felt by indigent Filipinos.

First and foremost is the promotion of community-based care services by investing in the construction of health centers at the village level or by organizing regular and frequent visits or caravans to help indigent people overcome the cost and transportation barriers that prevent them from participating in this health insurance program and benefiting from its benefits. Second, efforts must be made to provide all indigent members with clear, easy-to-understand, and detailed information about the full range of benefits offered by the Philippine Health Insurance Corporation. In addition, urgent and exceptional action is required at national, regional, and local levels to plan and implement health campaigns to raise awareness among indigents of common diseases and the importance of seeking timely healthcare services from appropriate providers. Finally, logistic and legislative measures must be in place to implement free medicine programs for indigent patients in poor and remote areas to enable these patients to access badly-needed medicines. 
Acknowledgements Open Access funding provided by the Qatar National Library.

Open Access This article is licensed under a Creative Commons Attribution 4.0 International License, which permits use, sharing, adaptation, distribution and reproduction in any medium or format, as long as you give appropriate credit to the original author(s) and the source, provide a link to the Creative Commons licence, and indicate if changes were made. The images or other third party material in this article are included in the article's Creative Commons licence, unless indicated otherwise in a credit line to the material. If material is not included in the article's Creative Commons licence and your intended use is not permitted by statutory regulation or exceeds the permitted use, you will need to obtain permission directly from the copyright holder. To view a copy of this licence, visit http://creativecommons.org/licenses/by/4.0/.

\section{References}

Bauhoff S, Hotchkiss DR, Smith O (2011) The impact of medical Insurance for the Poor in Georgia: a regression discontinuity approach. Health Econ 20(11):1362-1378

Bredenkamp C, Buisman L (2016) Financial protection from health spending in the Philippines: policies and Progress. Health Policy Plan 31(7):919-927

Buchmueller TC, Grumbach K, Kronick R, Kahn JG (2005) The effect of health insurance on medical care utilization and implications for insurance expansion: a review of the literature. Med Care Res Rev 62(1): 3-30

Dayrit MM, Lagrada LP, Picazo O, Pons MC, Villaverde MC (2018) The Philippines health system review. World Health Organization, Regional Office for South-East Asia https://apps.who.int/iris/handle/10665 /274579

Díaz JJ, Jaramillo M (2009) Evaluating interventions to reduce maternal mortality: evidence from Peru's PARSalud Programme. Journal of Development Effectiveness 1(4):387-412

Family Income and Expenditure Surveys (2012), realized by Philippine Statistics Authority - National Economic and Development Authority

Galarraga O, Sosa-Rubi SG, Salinas-Rodriguez A, Sesma-Vazquez S (2010) Health Insurance for the Poor: impact on catastrophic and out-of-pocket health expenditures in Mexico. Eur J Health Econ 11(5):437447

Giedion, U.; Eduardo Andres, A. and Yadira, D. (2013) The impact of universal coverage schemes in the developing world: a review of the existing evidence, Universal health coverage (UNICO) studies series; no. 25. Washington D.C.: The World Bank

Hadley J (2003) Sicker and poorer-the consequences of being uninsured: a review of the research on the relationship between health insurance, medical care use, health, work, and income. Med Care Res Rev 60(2 Suppl):3S-75S

Hahn J, Todd P, Van der Klaauw W (2001) Identification and estimation of treatment effects with a regression-discontinuity design. Econometrica 69(1):201-209

Johar M (2009) The impact of the Indonesian health card program: a matching estimator approach. J Health Econ 28(1):35-53

Jowett M, Hsiao WC (2007) The Philippines: extending coverage beyond the formal sector. In: Hsiao WC, Shaw RP (eds) Social health insurance for developing nations, Washington: the world bank, vol 2007, pp 81-104

King G, Gakidou E, Imai K, Lakin J, Moore TR, Ma CN et al (2009) Public policy for the poor? A randomised assessment of the Mexican universal health insurance Programme. Lancet 373(9673): 1447-1454

Makinen M, Konaté M (2005) "Evaluation de l'impact des systèmes d'assurance sanitaire sur l'utilisation des services de santé au Mali", Enquête sur la santé, Mali 1999, rapport. USA ID 386

National Statistics Office (NSO) [Philippines]. National Demographic and Health Survey (2013) Calverton. NSO and ORC Macro, Maryland

Pande R, Yazbeck A (2003) What's in a country average? Wealth, gender, and regional inequalities in immunization in India. Soc Sci Med 57(11):2075-2088

Panpiemras J, Puttitanun T, Samphantharak K, Thampanishvong K (2011) Impact of universal health care coverage on patient demand for health care services in Thailand. Health Policy 103(2-3):228-235 
Philippine Health Insurance Corporation (2014). The revised implementing rules and regulations of the National Health Insurance Act of 2014 (http://www.philhealth.gov.ph/about_us/irr_nhia2014.pdf, accessed 23 May 2016)

Philippines National Demographic and Health Survey (2013). Manila, Philippines, and Rockville, Maryland, USA: PSA and ICF International

Rosenbaum P, Rubin D (1983) The central role of propensity score matching in observational studies for causal effects. Biometrika 70:41-55

Savedoff WD, Levine R, Birdsall N (2006) When will we ever learn? Recommendations to improve social development through enhanced impact evaluation. The Center for Global Development, Washington, DC

Scheil-Adlung, X. and Jütting, J. (2006) What is the impact of social health protection on access to health care, health expenditure and impoverishment? A comparative analysis of three African countries. World Health Organization, World Health Organization \& International Labour Organization

Simon, J. and Barmeier, J. (2010) More than money: impact investing for development, The Center for Global Development

Smith KV, Sulzbach S (2008) Community-based health insurance and access to maternal health services: evidence from three west African countries. Soc Sci Med 66(12):2460-2473

Stuart, E.A. and Rubin, D.B. (2007) Best practices in quasi-experimental designs: matching methods for causal inference, Chapter 11 (pp. 155-176) in Best Practices in Quantitative Methods

The State of the World's Children 2013, United Nations Children's Fund

Thornton R, Hatt L, Field E, Islam M, Solís Diaz F, González MA (2010) Social security health insurance for the informal sector in Nicaragua: a randomized evaluation. Health Econ 19(Suppl):181-206

Trujillo A, Portillo J, Vernon V (2005) The impact of subsidized health Insurance for the Poor: evaluating the Colombian experience using propensity score matching. Int J Health Care Finance Econ 5(3):211-239

Wagstaff A (2010) Estimating health insurance impacts under unobserved heterogeneity: the case of Vietnam's health care fund for the poor. Health Econ 19(2):189-208

Wagstaff A, Moreno-Serra R (2009) Europe and Central Asia's great post-communist social health insurance experiment: aggregate impacts on health sector outcomes. J Health Econ 28(2):322-340

Wagstaff, A. and Pradhan, M. (2005) Health insurance impacts on health and nonmedical consumption in a developing country, World Bank Policy Research Working Paper No 3563

World Bank (2011) Philippine health sector review: challenges and future directions. World Bank, Washington, DC. http://documents.worldbank.org/curated/en/500561468295233918/Philippine-healthsector-review-challenges-and-future-directions

Yu B.; Meng Q.; Collins C.; Tolhurst R.; Tang S.; Yan F.; Bogg L. and Liu, X. (2010), How does the new cooperative medical scheme influence health service utilization? A study in two provinces in rural China, BMC Health Services research 10, Article number 116

Publisher's note Springer Nature remains neutral with regard to jurisdictional claims in published maps and institutional affiliations. 